craft development are all too acutely aware of the danger. The British aircraft industry has a long record of this kind of disappointment. The difficulty, of course, is very real. With limited money and limited manpower, it is tempting to cover as much ground as possible by spreading the available effort thinly. The consequence is often to ensure second place-or worse-in everything. In reality there is no escape from hard decisions to invest heavily in some projects and to ignore others.

How are decisions like these to be arrived at sensibly ? The first need, of course, is that those responsible for making such decisions should know how complicated is the task. It is now a long time since a man with imagination and a good eye could design an aircraft or, for that matter, a tea-cup. The close interaction between the process of design and miscellaneous activities such as market research and production engineering is a necessary feature of modern technology. Industry is not always aware of its problems--. and of the opportunities which their solution may present. Yet it may frequently be too much to ask that particular industries in isolation should make sensible decisions about their own affairs. In the last resort there is no substitute for a well-informed technical community within which there can be a vigorous appraisal of technical problems and opportunities. It is hard not to think that the decision about hovereraft in Britain would be much easier if it had been more widely argued.

\section{AVIATION NO MORE}

$\mathrm{T}$ HE disbandment of the Ministry of Aviation has been talked of for so long that the actual announcement a week ago came as something of a surprise. With $\mathrm{Mr}$. Fred Mulley, the Minister of Aviation, embattled with the other European members of ELDO, and with familiar anxiety about the costs of development projects such as Concord, it had begun to seem as if the Ministry's survival was assured for all time. For quite apart from the suspicion that the survival of the Ministry was a part of natural law, there was also the possibility that other ministers would be reluctant to take under the wings the troubles (and the capacity for inviting troubles) which have beset the Ministry of Aviation almost since its formation out of the old Ministry of Supply. But in any event the Ministry is to be dismembered in the summer. Most of it will go to the Ministry of Technology but responsibility for civil aviation, previously a dependant of the Ministry of Transport, will go to the Board of Trade.

The sequence of changes is important because the research establishments of the Ministry of Aviation are the most powerful research and development organizations in the United Kingdom. Though they are by no means exclusively harnessed to the needs of defence research, but on the contrary anxious to diversify their interests as much as possible, the establishments may now be able to make a greater contribution to civil research and development in the United Kingdom. That, at least, is what the Government is hoping. Fortunately the Ministry of Technology has by now lived through its early brashness, and so is unlikely to expect too much too quickly: that could be disastrous for morale at the establishments. The most urgent need is somehow to create the impression that this third major upheaval within three years of the administration of public science will, for the time being, be the last. If that can somehow be accomplished, the Government's hopes may easily be justified.

\section{DECODER MISLED?}

\section{Stonehenge Decoded}

By Gerald S. Hawkins in collaboration with John B. White. Pp. xiv $+202+23$ plates. (London: Souvenir Press, 1966.) 30s. net.

HIS book is an expansion of two articles in Nature $(200,306 ; 1963$, and 202,$1258 ; 1964)$. It is tendentious, arrogant, slipshod and unconvineing, and does little to advance our understanding of Stonehenge.

The first five chapters, on the legendary and archaeological background, have been uncritically compiled, and contain a number of bizarre interpretations and errors. The rest of the book is an unsuccessful attempt to substantiate the author's claim that "Stonehenge was an observatory; the impartial mathematics of probability and the celestial sphere are on my side". Of his two main contentions, the first concerns alignments between pairs of stones and other features, calculated with a computer from small-scale plans ill-adapted for this purpose. Their directions were compared with the azimuths of the rising and setting Sun and Moon, at the solstices and equinoxes, calculated for 1500 B.c. Any alignment falling within $+2^{\circ}$ of one of these eighteen azimuths is accepted, arbitrarily, as "significant". The limit of crror adopted is unrealistically large, since exporiment shows that such alignments can be laid out with a pair of sighting-sticks to a repeatable accuracy of $\pm 5 \mathrm{~min}$. Moreover, the assumption that the builders aimed at the full orb of the Sun and Moon, tangent to tho horizon, instead of at the first or last flash, is not confirmed by an analysis of the author's (unpublished) tables of vertical errors.

In claiming to have found thirty-two "significant" alignments, Hawkins has in five cascs exceeded his own limits of "significance". Furthermore, he has failed to show that his results are due to anything but chance. Even with the most favourable choice of data, no more than six of his alignments can be shown to be significant in the statistical sense. Before these can be accepted, they need to be measured on the site, and not from plans.

Hawkins's second contention is that the fifty-six Aubrey Holes were used as a "computer" (that is, as tally-marks) for predicting movements of the Moon and eclipses, for which he claims to have established a hitherto unrecognized 56-year cycle with 15 per cent irregularity; and that the rising of the full moon nearest the winter solstice over the Heel Stone always successfully predicted an eclipse. This, if substantiated, will provide the best explanation so far of this stone, though it should bo noted that no more than half these eclipses were visible from Stonehenge. As for the suggested use of the Aubrey Holes, it may be remarked that a ring of pits, filled up as soon as they had been dug, is not a very practicable form of permanent tally. Moreover, it is questionable whether a barbarous and illiterate community (for this is Stonehenge I, not Stonehenge III), which has left us no other evidence of numeracy, could successfully have recorded the data needed to establish a cycle which exceeded the contemporary life-span, and could not even have been recognized as a cycle until several generations had elapsed.

The fundamental objection to this and to other equally unconvincing suggestions in this book arises from the false logic of Prof. Hawkins's working hypothesis, declared in the preface. "If I can see any alignment, general relationship or use for the various parts of Stonehenge," he says, "then these facts were also known to the builders." As he so truly adds in the next sentence, "Such a hypothesis has carried me along over many incredible steps".

\section{R. J. C. Atrinson}

